\title{
Comparative age and growth of common snook Centropomus undecimalis (Pisces: Centropomidae) from coastal and riverine areas in Southern Mexico
}

\author{
Martha A. Perera-Garcia ${ }^{1}$, Manuel Mendoza-Carranza ${ }^{2}$, Wilfrido Contreras-Sánchez ${ }^{3}$, \\ Allyse Ferrara ${ }^{4}$, Maricela Huerta-Ortiz ${ }^{3}$ \& Raúl E. Hernández-Gómez ${ }^{1}$ \\ 1. División Académica Multidisciplinaria de los Ríos, Universidad Juárez Autónoma de Tabasco, Col. Solidaridad S/N, \\ C.P. 86901, Tenosique, Tabasco, México; martha.perera@damr.ujat.mx \\ 2. El Colegio de la Frontera Sur (ECOSUR), Carretera Villahermosa/Reforma, Kilómetro 15.5, Ranchería Guineo 2a. \\ Sección, C.P. 86280, Villahermosa, Tabasco, México; mcarranza@ecosur.mx \\ 3. División Académica de Ciencias Biológicas, Universidad Juárez Autónoma de Tabasco, Apdo. Postal 967. C.P.86101, \\ México. Villahermosa, Tabasco, México; contrerw@hotmail.com, mahuor13@hotmail.com \\ 4. Nicholls State University, Department of Biological Sciences, 223 Gouaux Hall, Thibodaux, LA 70310, USA; \\ allyse.ferrara@nicholls.edu
}

Received 13-XII-2011. C Corrected 25-VIII-2012. Accepted 24-IX-2012.

\begin{abstract}
Common snook Centropomus unidecimalis is an important commercial and fishery species in Southern Mexico, however the high exploitation rates have resulted in a strong reduction of its abundances. Since, the information about its population structure is scarce, the objective of the present research was to determine and compare the age structure in four important fishery sites. For this, age and growth of common snook were determined from specimens collected monthly, from July 2006 to March 2008, from two coastal (Barra Bosque and Barra San Pedro) and two riverine (San Pedro and Tres Brazos) commercial fishery sites in Tabasco, Mexico. Age was determined using sectioned saggitae otoliths and data analyzed by von Bertalanffy and Levenberg-Marquardt among others. Estimated ages ranged from 2 to 17 years. Monthly patterns of marginal increment formation and the percentage of otoliths with opaque rings on the outer edge demonstrated that a single annulus was formed each year. The von Bertalanffy parameters were calculated for males and females using linear adjustment and the non-linear method of Levenberg-Marquardt. The von Bertalanffy growth equations were $\mathrm{FL}_{\mathrm{t}}=109.21\left(1-\mathrm{e}^{-0.21(\mathrm{t}+0.57)}\right)$ for Barra Bosque, $\mathrm{FL}_{\mathrm{t}}=94.56\left(1-\mathrm{e}^{0.27(\mathrm{t}+0.48)}\right)$ for Barra San Pedro, $\mathrm{FL}_{\mathrm{t}}=97.15\left(1-\mathrm{e}^{-0.17(\mathrm{t}+1.32)}\right)$ for San Pedro and $\mathrm{FL}_{\mathrm{t}}=83.77\left(1-\mathrm{e}^{-0.26(\mathrm{t}+0.49)}\right)$ for Tres Brazos. According to (Hotelling's $\left.\mathrm{T}^{2}, \mathrm{p}<0.05\right)$ test growth was significantly greater for females than for males. Based on the Chen test, von Bertalanffy growth curves were different among the study sites (RSS, $\mathrm{p}<0.05$ ). Based on the observed differences in growth parameters among sampling sites (coastal and riverine environments) future research need to be conducted on migration and population genetics, in order to delineate the stock structure of this population and support management programs. Rev. Biol. Trop. 61 (2): 807-819. Epub 2013 June 01.
\end{abstract}

Key words: Centropomidae, otolith, population structure, growth rate artisanal fishery.

Common snook, Centropomus undecima$l i s$, is a protandric hermaphrodite species with a diadromous life history (Taylor et al. 2000, Tavares \& Luque 2003, Muller \& Taylor 2006), distributed in the Eastern Atlantic Ocean from Northern Florida, USA to Southern Brazil (Rivas 1986, Brennan et al. 2006). Common snook is abundant in coastal states of Gulf of Mexico (Tamaulipas, Veracruz, and Tabasco)
(Caballero 2003, Zarza-Meza et al. 2006). However, in recent years, the high exploitation rates by the commercial and recreational fisheries had resulted in a strong decrease of its abundance in many coastal areas of the Gulf of Mexico (Chacón 1993, Quiroga \& Solís 1999, Caballero 2003, Muller \& Taylor 2006).

The increase in fishing mortality changes population structure, particularly age structure 
and reproduction efficiency (Cadima 2003). The impacts of increased fishing mortality are usually more acute in tropical regions, where food availability is often lower as well as metabolic demands greater than in temperate regions (Brennan et al. 2006, Stevens et al. 2007). Age structure is useful to compare population's dynamics under different exploitation rates or different environments occupied by species (Sparre \& Venema 1997). Periodic assessments regarding age, growth, and abundance are basic to determine the effects due to changes of environmental variables and catch rates over the exploited populations (Pauly et al. 2002).

Comparative studies about common snook in Florida, USA, showed differences in the growth and reproductive parameters of two populations (Eastern and Western) of Florida. This was related to the reproductive isolation between these two populations and differences in exploitation rates (Marshall 1958, Aliaume et al. 2000, Taylor et al. 2000, Muller \& Taylor 2006). In México, both studies about age and growth of common snook has been limited to coastal zones; these studies have been observed by Caballero (2003), who identified nine age-classes using whole otoliths readings, indicating that it is a slow growing species with a longevity from 21 to 28 years old.

Considering that common snook is a diadromous species with a life cycle which is strongly related to riverine migrations, it is important to know its population dynamic along its distribution range and to test for populational differences regarding its life cycle and reproductive migration along rivers. In Tabasco, the fishery of common snook is strongly related to its life cycle. The highest catches are in accordance with its reproductive migrations between riverine and coastal marine areas; during winter, the mature individuals migrate upstream whereas in summer they migrate to coastal areas to spawn (Perera-García et al. 2008, Perera-Garcia et al. 2011). However, this movement as well as age structure of spawning aggregations are poorly understood (McDowall 1999).
In Tabasco state, small-scale fishery fleets exploit common snook within coastal marine and riverine environments by using special gillnets made out of multifilament nylon (PereraGarcía et al. 2008). This species represents a significant monetary income and alimentary resource for all rural communities nearby its distribution. Based on the economical importance of this species and its life cycle, the aim of this study was to determine and compare the age structure and growth rates of common snook individuals, collected from small scalefisheries of two coastal and two riverine areas in Tabasco, Mexico.

\section{MATERIALS AND METHODS}

Study area and sampling survey: Common snook individuals and otoliths were obtained from four commercial landing points located in coastal and riverine areas during monthly sampling surveys conducted from July 2006 to March 2008. Fish were obtained from small-scale fisheries by using multifilament gillnets with a six centimeters $(\mathrm{cm})$ mesh size, 10-100m length and $2 \mathrm{~m}$ height.

We sampled two coastal areas, Barra Bosque located in the Grijalva River mouth (18 36 '52" N - 92॰41'07"W) and Barra San Pedro located at the San Pedro and San Pablo River mouth (18³8'59' N - 9241'07' W), as well as in two riverine areas, Tres Brazos $\left(18^{\circ} 23^{\prime} 50^{\prime \prime} \mathrm{N}-92^{\circ} 38^{\prime} 52^{\prime}\right.$ 'W) and San Pedro (17 $46^{\prime} 13^{\prime \prime} \mathrm{N}-91^{\circ} 09^{\prime} 17^{\prime}$ 'W) located along the Usumacinta River (Fig. 1). A total of 104 and 114 individuals from Barra Bosque and Barra San Pedro were respectively collected, while 36 and 314 individuals were collected from Tres Brazos and San Pedro, respectively. For each specimen, fork length (FL, in $\mathrm{cm}$ ) and somatic weight ( $\mathrm{SW}$, in $\mathrm{g}$ ) were obtained, sex was determined macroscopically by gonads observation, and the right sagittae otoliths were extracted by cutting inside the operculum area, and were stored for later processing.

Laboratory samples processing: A low speed Buehler® IsoMet巴 1000 saw equipped 


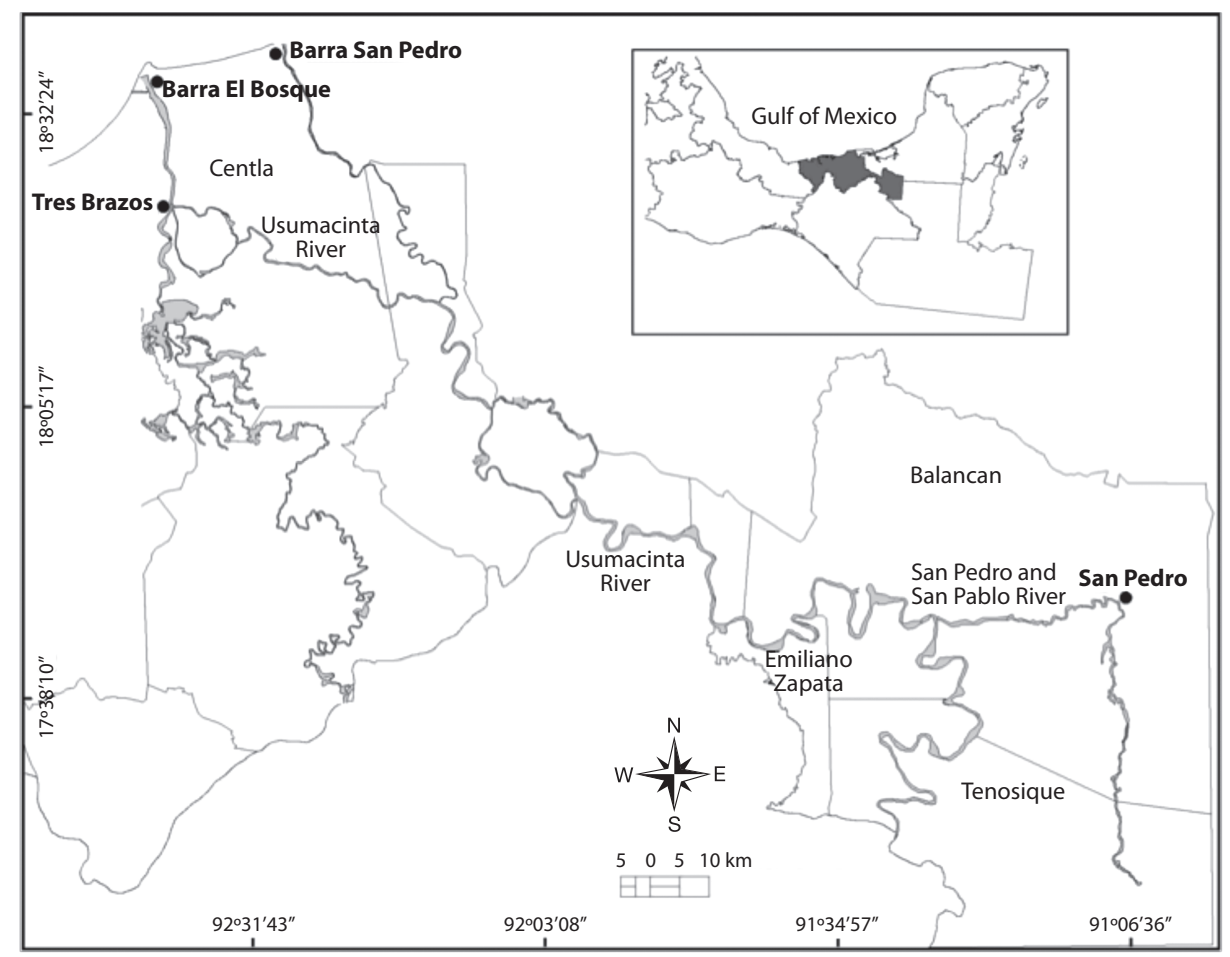

Fig. 1. Sampling points of common snook, C. undecimalis, Tabasco, México.

with diamond wafering blades was used to cut 0.5 millimeters $(\mathrm{mm})$ transverse sections from each right sagittae otolith (Taylor et al. 2000). Otolith sections were polished with sandpaper (2000 caliber); afterwards, sections were mounted on clean slides with Crystal Bond ${ }^{\mathrm{TM}}$ \#509 thermoplastic cement (Electron Microscopy Supply, Inc.).

Images of 7.5 megapixels of each otolith section were obtained under transmitted light using a stereoscopic microscope Stemi DV4 (Carl-Zeiss) fitted with a Cannon ${ }^{\mathrm{TM}}$ Power Shot G6 digital camera. Then, the age of each individual was obtained by two different readers by direct counting of the age marks (opaque and translucent bands) (Taylor et al. 2000, Campana 2005). Disagreement between readers was addressed by a concert read. However, if differences in age determination were persisting, the otolith was discarded (Beamish \& McFarlane 1983, Taylor et al. 2000). Eighty-six (13.15\%) collected otoliths were discarded. Additionally, the distance from the otolith core to the edge along sulcus ridge (otolith radius) and the distance from the core to each opaque band were measured with a micrometer (Fig. 2).

In order to test for seasonality in the bands formation, a cross correlation analysis was performed between the monthly proportion of marginal translucent and opaque bands with the monthly average sea surface temperature of the sampled period (Perera-Garcia et al. 2011). The monthly average sea surface temperature along the fishing area was estimated from weekly sea surface temperature images taken from module MODIS on Aqua (Ocean Watch North Pacific Demonstration Project, 2012).

The von Bertalanffy (1957) growth model was fitted to the observed length-at-age and weight-at-age. The model was described by the equations: $\mathrm{L}_{\mathrm{t}}=\mathrm{L}_{\infty}\left(1-\mathrm{e}^{-k(\mathrm{t}-\mathrm{to})}\right)$ and $\mathrm{W}_{\mathrm{t}}=\mathrm{W}_{\infty}$ $\left(1-\exp ^{-k(t-t o)}\right)^{b}$, where: $\mathrm{L}_{\mathrm{t}}=$ average fork length at age ${ }_{t} ; L_{\infty}=$ asymptotic fork length; $\mathrm{W}_{\mathrm{t}}=$ average weight at age $; \mathrm{W}_{\infty}=$ asymptotic weight; 


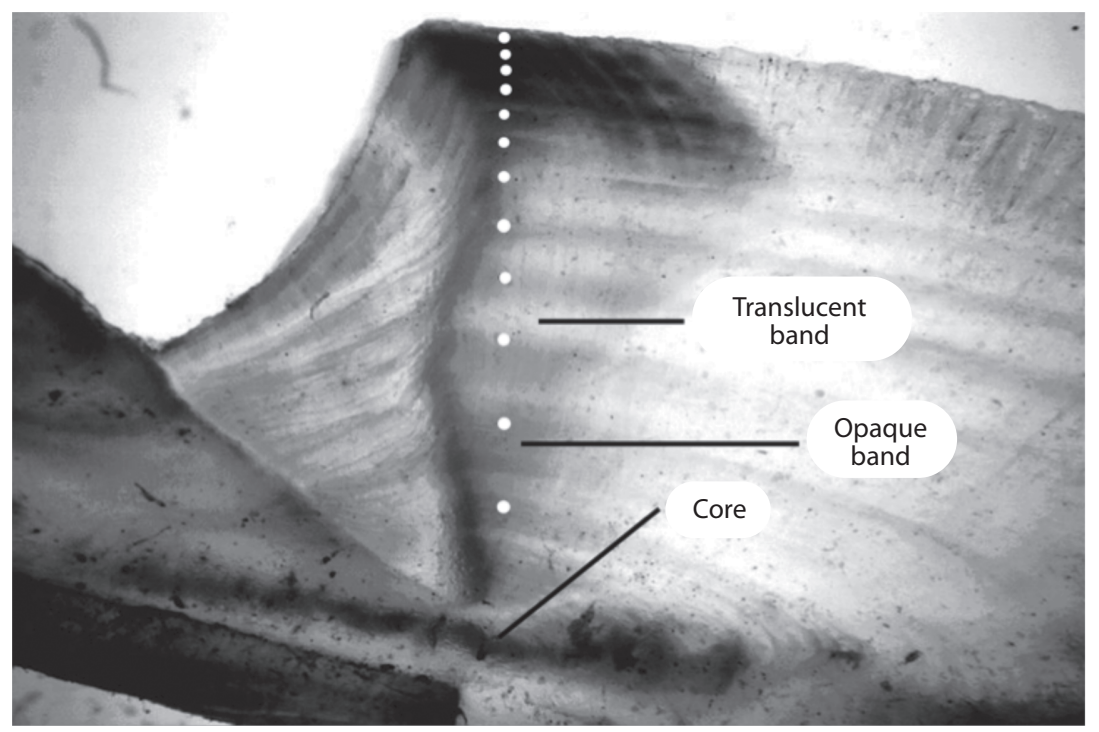

Fig. 2. Transverse otolith section of 12-year-old male $(\mathrm{FL}=89.5 \mathrm{~cm})$ of $C$. undecimalis, Tabasco, México.

$\mathrm{t}_{0}=$ hypothetical length or weight at age zero; $k$ is the growth coefficient; and b is the slope of the length-weight relationship.

Growth parameters were estimated for combined sexes using Ford-Walford's linear methods (Walford 1946) for a first estimation, and were calculated linearizing the VBGF; these first estimates were used as "seeds" to estimate the final growth parameters by means of a non-linear regression using LevenbergMarquardt's algorithm (Saila et al. 1988, Sparre \& Venema 1997, Rico et al. 2001).One year old specimens were not collected, therefore the average FL for this age class was calculated in $28 \mathrm{~cm}$, based on back-calculated lengths and also comparing with published data (Mejia \& Lara 2007).

The length-weight relationship was determined by using the nonlinear equation: $\mathrm{SW}=\mathrm{aFL}^{\mathrm{b}}$ where: $\mathrm{SW}$ is the somatic weight, $a$ is the intercept (initial growth coefficient or condition factor), FL is the fork length, and $b$ is the slope (growth coefficient, which indicates the isometric or allometric growth) (Ricker 1973). Data for growth by length and the weight-length relationship were used to obtain the weight for each age. To determine the relationship between otolith radius (OR) and FL we used the regression: $\mathrm{FL}=\mathrm{aOR}^{\mathrm{b}}$ for both sexes combined (Ricker 1973, Ehrhardt 1992).

For determining back-calculation, we used three methods which were developed using scales to back-calculate FL (found in Francis, 1990): the Fraser-Lee (1910) model, $\mathrm{L}_{\mathrm{i}}=\left(\mathrm{R}_{\mathrm{i}} /\right.$ $\left.\mathrm{R}_{\mathrm{C}}\right) *\left(\mathrm{~L}_{\mathrm{c}}-\mathrm{c}\right)+\mathrm{c}$, the Dahl-Lea (1910) model, $\mathrm{L}_{\mathrm{i}}=\left(\mathrm{R}_{\mathrm{i}} / \mathrm{R}_{\mathrm{C}}\right) * \mathrm{~L}_{\mathrm{c}}$, and the Whitney-Carlander model, $\quad \mathrm{L}_{\mathrm{i}}=-(\mathrm{a} / \mathrm{b})+(\mathrm{FL}+\mathrm{a} / \mathrm{b})\left(\mathrm{S}_{\mathrm{i}} / \mathrm{S}_{\mathrm{c}}\right)$, where $\mathrm{L}_{\mathrm{i}}=$ age at which the first ring was formed; $\mathrm{R}_{\mathrm{i}}=$ distance to each ring (distance from core to $\mathrm{i}^{\text {th }}$ ring); $\mathrm{R}_{\mathrm{C}}=$ otolith radius or periphery distance; $\mathrm{L}_{\mathrm{c}}=$ average $\mathrm{FL}$; and $\mathrm{c}=$ correction factor (intercept of the regression equation for $\mathrm{OR}$ on FL). Average FL-at-observed-age was used to support the back-calculation procedures (Ricker 1992, Ibañez et al. 2008).

To assess the formation of annual growth bands, the monthly frequency of otolith edge or margin translucence of each sectioned otolith was recorded. Monthly ratios of marginal translucence were compared using $X^{2}$ test. An analysis of covariance (ANCOVA) defined differences among the slopes with FL as the covariable (Zar 1999). An ANCOVA was used to test for differences between observed FL 
and back-calculated FL (Zar 1999). Hotelling's $\mathrm{T}^{2}$-test was used to compare growth curves of males and females; this test assumes that the estimates of $L_{\infty}, k$ and $\mathrm{t}_{0}$ of combined sexes were obtained from normal distributions (Bernard 1981). The differences in the von Bertalanffy growth parameters among the four sample sites were compared by using the residual sum of squares analyses (RSS) (Chen et al. 1992). A multiple correlation analysis and an analysis of covariance (ANCOVA) were applied to the FL-SW regressions to assess differences between the sexes (Sokal \& Rohlf 1996, Zar 1999).

\section{RESULTS}

The fork length of common snook individuals from Barra Bosque ranged from 38 to $111.5 \mathrm{~cm}$ (average $\pm \mathrm{SD}$ ), while in Barra San Pedro ranged from 33 to $108 \mathrm{~cm}$, (average \pm SD), in San Pedro from 44 to $88.5 \mathrm{~cm}$ (average $\pm \mathrm{SD}$ ) and in Tres Brazos from 30 to $88 \mathrm{~cm}$ (average $\pm \mathrm{SD}$ ). The ANCOVA analyses show that the FL-SW relationship was not statistically different between males and females for all sampling points. Accordingly, we herein present the general equations for the FL-SW relationship for each sampling point: Barra Bosque $\mathrm{SW}=0.0062 * \mathrm{FL}^{2.6}$ $\left(\mathrm{r}^{2}=0.91\right)$, Barra San Pedro $\mathrm{SW}=0.0042 * \mathrm{FL}^{3.0}$ $\left(\mathrm{r}^{2}=0.97\right)$; and riverine area were: San Pedro $\mathrm{SW}=0.0067 * \mathrm{FL}^{3.0}\left(\mathrm{r}^{2}=0.90\right)$ and Tres Brazos $\mathrm{SW}=0.0058 * \mathrm{FL}^{3.0}\left(\mathrm{r}^{2}=0.92\right)$.

The marginal bands formation in the otoliths of the common snook was related with seasonal variation temperature. Translucent bands are formed predominantly during months with low sea surface temperature from November to April (Average temperature $=25.9 \pm 0.75^{\circ} \mathrm{C}$ ), whereas the greatest proportions $(0.70>)$ of translucent bands occurred during January to April (Fig. 3). Opaque marginal band formation has been related to a high temperature period from May to September (Average temperature $=29.1 \pm 0.43^{\circ} \mathrm{C}$ ), meanwhile the greatest proportion $\left(0.60^{3}\right)$ of opaque bands occurred during May to August (Fig. 3).

The cross correlation showed a significant correlation $(0.60>)$ among low temperatures

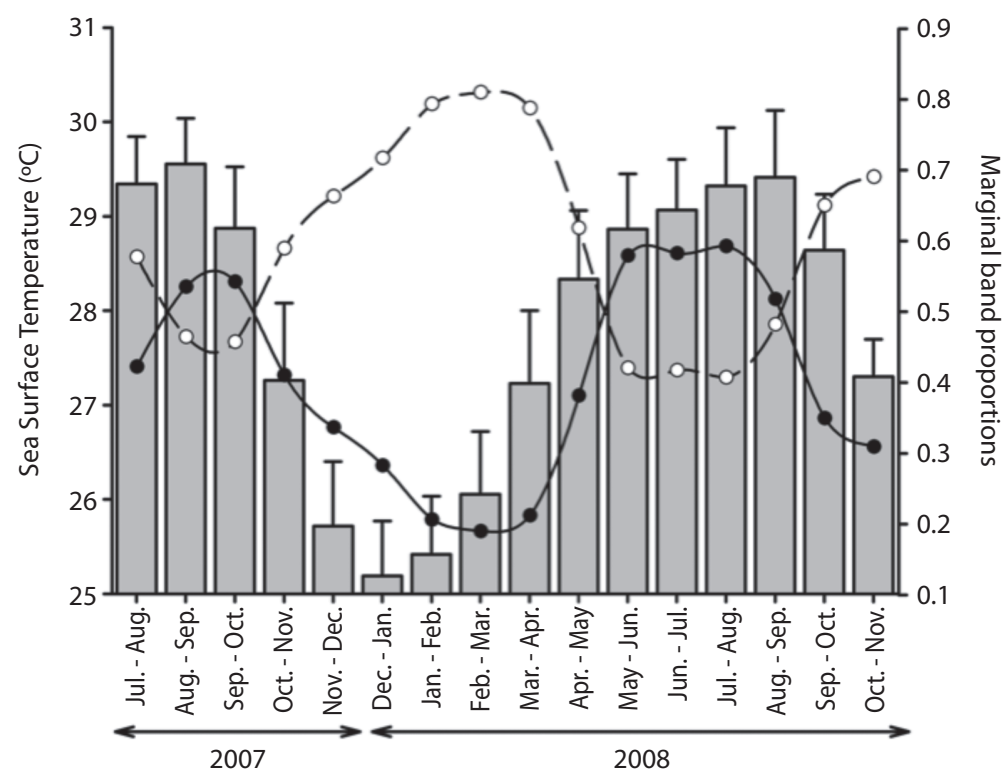

Fig. 3. Monthly frequency of the opaque $(\bullet)$ and translucent $(O)$ marginal bands of $C$. undecimalis associated sea surface temperatures, coastal zone, Tabasco, México. 
with high proportions of translucent bands almost during two months before and after lowest sea surface temperature (Fig. 4). In the case of opaque bands, the cross correlation function showed a significant correlation $(0.60>)$ among high temperatures and highest proportions of opaque bands almost during one month before and after the highest temperatures. Monthly patterns in marginal bands proportions showed that the formation of a pair of bands (translucent-opaque) occurring during one year approximately (Fig. 4).

Linear relationships were found between FL and OR of common snook for each site at the coastal and riverine areas. Correlation coefficients between FL and OR were significant $(\mathrm{p}<0.01)$ for each site indicating that the otolith radius was correlated with FL for ages 2-17:

Barra Bosque

$\mathrm{FL}=35.931+5.016^{*} \mathrm{OR}\left(\mathrm{n}=104, \mathrm{r}^{2}=0.82, \mathrm{p}<0.01\right)$

Barra San Pedro

$\mathrm{FL}=16.773+6.601 * \mathrm{OR}\left(\mathrm{n}=114, \mathrm{r}^{2}=0.88, \mathrm{p}<0.01\right)$
San Pedro

$\mathrm{FL}=16.030+6.665 * \mathrm{OR}\left(\mathrm{n}=314, \mathrm{r}^{2}=0.75, \mathrm{p}<0.01\right)$

Tres Brazos

$\mathrm{FL}=14.568+6.741 * \mathrm{OR}\left(\mathrm{n}=36, \mathrm{r}^{2}=0.42, \mathrm{p}<0.01\right)$

The significant relation between FL and OR for each site supports the use of otoliths to determine age and growth rates and to perform back-calculations of size-at-age for common snook. However, because so few specimens were collected in Tres Brazos, these results must be considered with caution. Covariance analysis showed differences $(\mathrm{F}=21.28, \mathrm{p}<0.001)$ in the FL-OR relationship for the different sampling sites, thus there were geographical differences in otoliths and fish growth rates. Fish from the coastal area were larger-at-age and therefore grew faster than fish from riverine areas.

The Whitney-Carlander method overestimated FL when compared to observed lengths-at-age, whereas the other methods underestimated FL (Fig. 5). The mean observed FL at age and those obtained by back-calculation

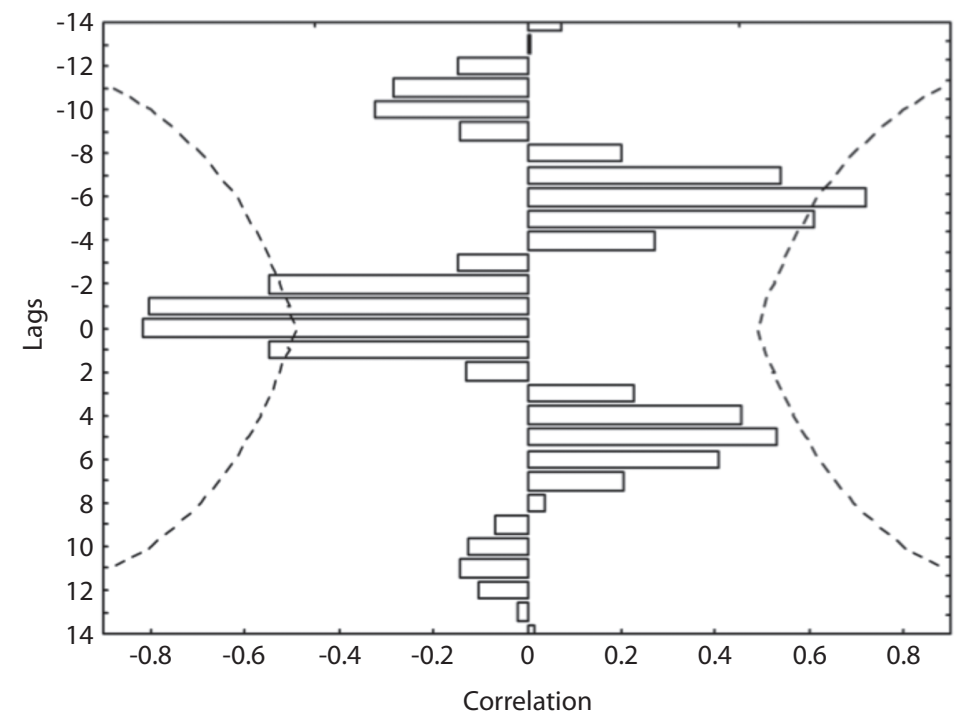

Fig. 4. Cross correlation coefficient for opaque and translucent margins and sea surface temperature, coastal area of Tabasco, México. 


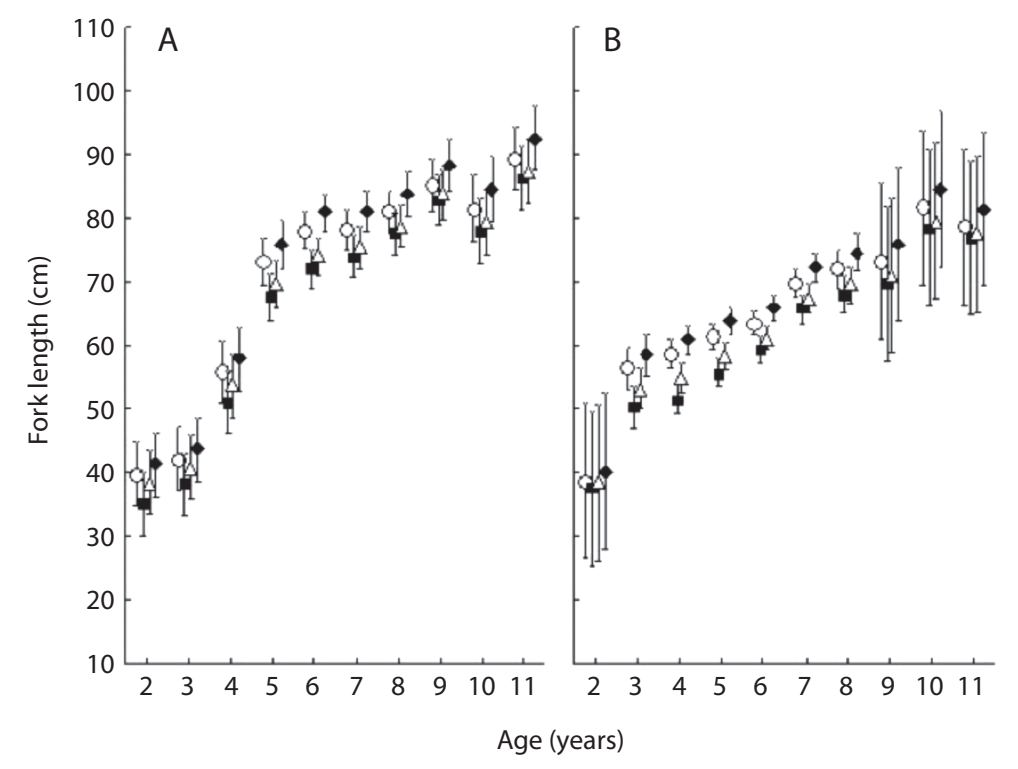

Fig. 5. Mean lengths observed (FL) (O) and back-calculation models for each scale. Fraser-Lee $(\diamond)$, Dahl-Lea $(\mathbf{\square})$ and Whitney-Calander $(\Delta)$ methods for $C$. undecimalis, coastal (A) and riverine area (A), Tabasco, México.

methods for the coastal and riverine grouped areas were different (ANCOVA, $\mathrm{F}=13.02$, $\mathrm{p}<0.05 ; \mathrm{F}=45.09, \mathrm{p}<0.05)$. However, Tukey's test failed to find differences $(p>0.05)$ in the back-calculated mean FL of snook from the coastal area, which was obtained by the DahlLea and Fraser-Lee methods, and the observed FL using the Whitney-Carlander method. Although some discrepancies were found (calculated lengths for snook age two were similar for the coastal and the riverine areas), backcalculated FL was greater for the area of snook age five and older.

Estimated ages ranged from two to 16 years (in Barra San Pedro) with females having larger coefficients and larger sizes in all four sites. The population of $C$. undecimalis in the riverine area was younger with a maximum age of 11 years (female in San Pedro and males in Tres Brazos), whereas, the coastal population included larger and older individuals up to 17 years of age (Table 1).

The von Bertalanffy growth parameters of sexes combined for coastal areas were: Barra Bosque $\mathrm{FL}_{\mathrm{t}}=109.21\left(1-\mathrm{e}^{-0.21(\mathrm{t}+1.39)}\right)$,
Barra San Pedro $\mathrm{FL}_{\mathrm{t}}=94.56\left(1-\mathrm{e}^{0.27(\mathrm{t}+0.23)}\right)$; for the riverine areas were: San Pedro $\mathrm{FL}_{\mathrm{t}}=97.15\left(1-\mathrm{e}^{-0.17(\mathrm{t}+0.91)}\right)$ and Tres Brazos $\mathrm{FL}_{\mathrm{t}}=83.76\left(1-\mathrm{e}^{-0.26(\mathrm{t}+0.49)}\right)$. The growth curves for the coastal and riverine areas are presented herein (Fig. 6 and 7). Significant differences in the growth parameters were found between males and females, where Hotelling's $\mathrm{T}^{2}$-test is for Barra Bosque $\left(\mathrm{T}^{2}{ }_{\text {obs }}=771.13>\mathrm{T}^{2}=12.19\right.$, $\mathrm{p}<0.001)$, for Barra San Pedro $\left(\mathrm{T}^{2}{ }_{\text {obs }}=936.54>\mathrm{T}^{2}=12.11, \mathrm{p}<0.001\right)$ and for San Pedro $\left(\mathrm{T}^{2}{ }_{\text {obs }}=720.64>\mathrm{T}^{2}=11.61, \mathrm{p}<0.001\right)$.

The average size of males was smaller than the average size of females of the same age. Additionally, the residual sum of square, RSS, indicated that the von Bertalanffy growth curves varied among areas $(\mathrm{F}=74.08, \mathrm{p}<0.05)$.

\section{DISCUSSION}

In our study area, the translucent band was deposited mostly during the summer, with regard to high temperature and food abundance. The opaque band formed each winter, has been attributed to slow growth with regard to 
TABLE 1

Average fork length $(\mathrm{cm})$ at age of males and females of common snook, C. undecimalis, in the sampling points

\begin{tabular}{|c|c|c|c|c|c|c|c|c|}
\hline \multirow{3}{*}{$\begin{array}{c}\text { Age } \\
\text { (years) }\end{array}$} & \multicolumn{4}{|c|}{ Coastal area } & \multicolumn{4}{|c|}{ Riverine area } \\
\hline & \multicolumn{2}{|c|}{ Barra el Bosque } & \multicolumn{2}{|c|}{ Barra San Pedro } & \multicolumn{2}{|c|}{ San Pedro } & \multicolumn{2}{|c|}{ Tres Brazos } \\
\hline & $\begin{array}{c}\text { Males } \\
\mathrm{FL} \pm \mathrm{SD}\end{array}$ & $\begin{array}{l}\text { Females } \\
\mathrm{FL} \pm \mathrm{SD}\end{array}$ & $\begin{array}{c}\text { Males } \\
\mathrm{FL} \pm \mathrm{SD}\end{array}$ & $\begin{array}{l}\text { Females } \\
\text { FL } \pm \text { SD }\end{array}$ & $\begin{array}{c}\text { Males } \\
\mathrm{FL} \pm \mathrm{SD}\end{array}$ & $\begin{array}{l}\text { Females } \\
\mathrm{FL} \pm \mathrm{SD}\end{array}$ & $\begin{array}{c}\text { Males } \\
\mathrm{FL} \pm \mathrm{SD}\end{array}$ & $\begin{array}{l}\text { Females } \\
\mathrm{FL} \pm \mathrm{SD}\end{array}$ \\
\hline 2 & - & - & $39.8 \pm 3.6$ & - & 44.5 & - & 33.0 & - \\
\hline 3 & 39.5 & - & $42.3 \pm 10.3$ & - & $58.7 \pm 7.1$ & 57.5 & $48.0 \pm 10.6$ & - \\
\hline 4 & 53.5 & - & $56.0 \pm 18.4$ & - & $60.7 \pm 6.5$ & $63.8 \pm 1.0$ & $49.3 \pm 13.7$ & 60.0 \\
\hline 5 & $69.5 \pm 11.2$ & $81.0 \pm 2.3$ & $75.2 \pm 11.2$ & 58.2 & $60.8 \pm 7.3$ & $70.6 \pm 9.1$ & $56.8 \pm 12.5$ & - \\
\hline 6 & $77.5 \pm 6.9$ & $81.6 \pm 7.2$ & $74.3 \pm 7.6$ & $83.9 \pm 6.8$ & $63.1 \pm 7.0$ & $70.2 \pm 8.8$ & $62.2 \pm 11.0$ & - \\
\hline 7 & $74.2 \pm 11.8$ & $83.6 \pm 6.8$ & $78.8 \pm 4.9$ & $82.0 \pm 9.8$ & $68.2 \pm 6.5$ & $72.3 \pm 6.5$ & 77.5 & - \\
\hline 8 & $76.9 \pm 4.4$ & $84.2 \pm 6.8$ & $77.9 \pm 6.2$ & $88.5 \pm 10.0$ & $70.2 \pm 6.1$ & $72.1 \pm 7.2$ & $70.5 \pm 3.5$ & - \\
\hline 9 & $78.4 \pm 6.6$ & $89.9 \pm 8.8$ & $78.3 \pm 3.7$ & $94.7 \pm 12.7$ & $76.5 \pm 2.8$ & 70.0 & $73.2 \pm 1.0$ & 88.0 \\
\hline 10 & $80.7 \pm 4.0$ & $81.3 \pm 1.9$ & $82.2 \pm 6.5$ & - & - & 81.6 & - & - \\
\hline 11 & 74.5 & $90.2 \pm 3.8$ & $83.5 \pm 1.4$ & $93.9 \pm 8.8$ & - & 82.0 & 75.0 & - \\
\hline 12 & $75.7 \pm 3.8$ & $103.3 \pm 1.5$ & $83.7 \pm 4.0$ & $87.6 \pm 7.0$ & - & - & - & - \\
\hline 13 & - & $98.8 \pm 9.4$ & 85.5 .8 & $97.1 \pm 2.3$ & - & - & - & - \\
\hline 14 & 91.5 & - & - & - & - & - & - & - \\
\hline 15 & - & $99.2 \pm 8.8$ & - & - & - & - & - & - \\
\hline 16 & - & - & & 97.5 & - & - & & \\
\hline 17 & - & - & 94.5 & - & - & - & - & - \\
\hline
\end{tabular}

$\mathrm{FL}=$ fork length, $\mathrm{SD}=$ standard deviation.

reproduction, spawning and low temperature (Tucker and Campbell 1988, Taylor et al. 2000, Chen et al. 2008). During the reproductive period, the metabolic energy appeared to have been diverted from somatic growth, resulting in the formation of narrow opaque zones as compared to relatively wider translucent zones (Lorenzo et al. 2002, Villamil et al. 2002, Kallianiotis et al. 2005). Seasonal deposition of age marks in otoliths of $C$. undecimalis was consistent across sampling years and sites. This pattern of annular marks on hard structures has been related to both temporal variations in availability of food resources and temperature (Cappo et al. 2000, Melo \& Felix 2004, Lin \& Tzeng 2009).

The highly correlated linear regression of $\mathrm{FL}$ and $\mathrm{OR}$ of $C$. undecimalis showed that rings on otoliths are suitable structures to estimate individual growth rates and can be used to back calculate sizes at previous ages (Aliaume et al. 2000, Taylor et al. 2000, Cabrera 2002). The different growth rates observed in males and females were related to sex change (Villamil et al. 2002, Munday et al. 2004, Walter \& McCormick 2004). In common snook, growth increments were larger for females, indicating that females had faster growth rates and were larger-at-age than males (Taylor et al. 2000, Patterson et al. 2005). Growth rates ( $k$ ) were faster in the coastal area than in the riverine area and may be related to greater abundance of food and lower population density in the coastal area (Caballero 2003, Aliaume et al. 2005, Steven et al. 2007).

Our sizes-at-age were similar to those reported for common snook in Puerto Rico and Florida (Aliaume et al. 2000, Patterson et al. 2005, Taylor et al. 2000), although we had to account for sub-annual increments or narrow translucent, "false," rings (Campana 2001). Additionally, in the case of older specimens, opaque rings on the otoliths edge were closely and accounted for most of the reconciled discrepancies (Villamil et al. 2002, Wilson et al. 2009). 


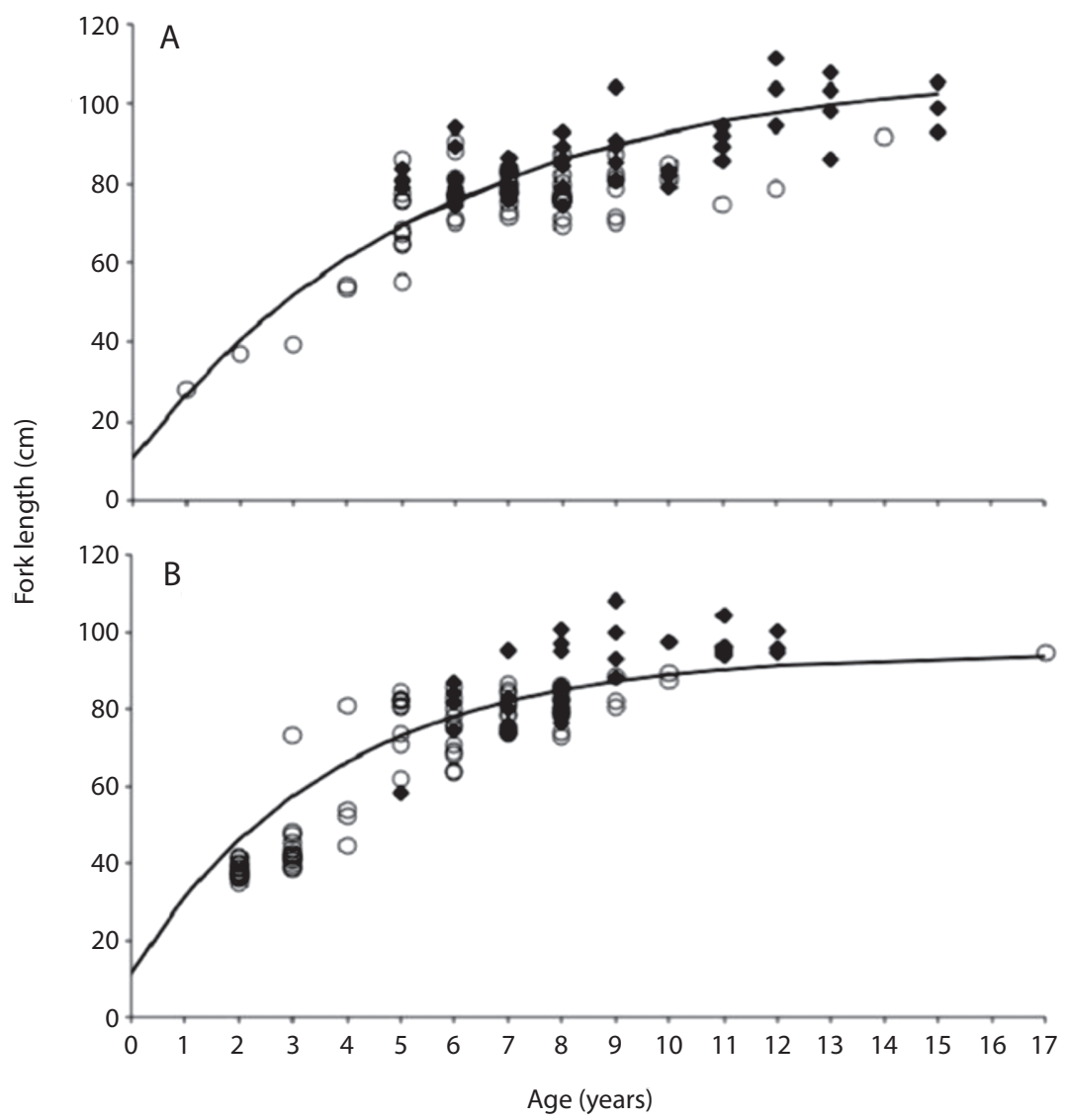

Fig. 6. The von Bertalanffy growth curves for males $(O)$ and females $(>)$ of $C$. undecimalis, coastal area, Tabasco, México.

Most of the specimens collected from the coastal area of Tabasco, were mature females over five years old, whereas, specimens collected in the riverine area were mostly males. The differences in the size-at-age ranges for males and females of the common snook, between coastal and riverine areas, is consequence of sexual segregation, a general characteristic of the common snook populations, which is normally associated with reproduction, migration, competition or environmental factors that influence growth and determine the size (Peters et al. 1998, Aliaume et al. 2005, Patterson et al. 2005, Chen et al. 2008). Barra Bosque and Barra San Pedro, are defined as areas of recruitment for spawning and breeding then is common to find old females in advanced reproductive stages (Perera-Garcia et al. 2008); whereas in the riverine area, younger common snooks are found, this segregation is related to migration and reproductive habits of this species. Stevens et al. (2007) observed C. undecimalis in prejuvenil stage $(<15 \mathrm{~cm})$ and juvenile (15 to $35 \mathrm{~cm}$ standard length) are abundant in estuarine habitats. However, they found that juveniles dominate riparian habitats. On the other hand, juveniles migrate into certain sizes within freshwater tributaries, which later on cause them to have difficulties for returning into isolated localities, due to their dependence on water levels that established connectivity with adjacent habitats. This could indicate the reason of the results obtained in this study in the riverine area, where the range of size and 


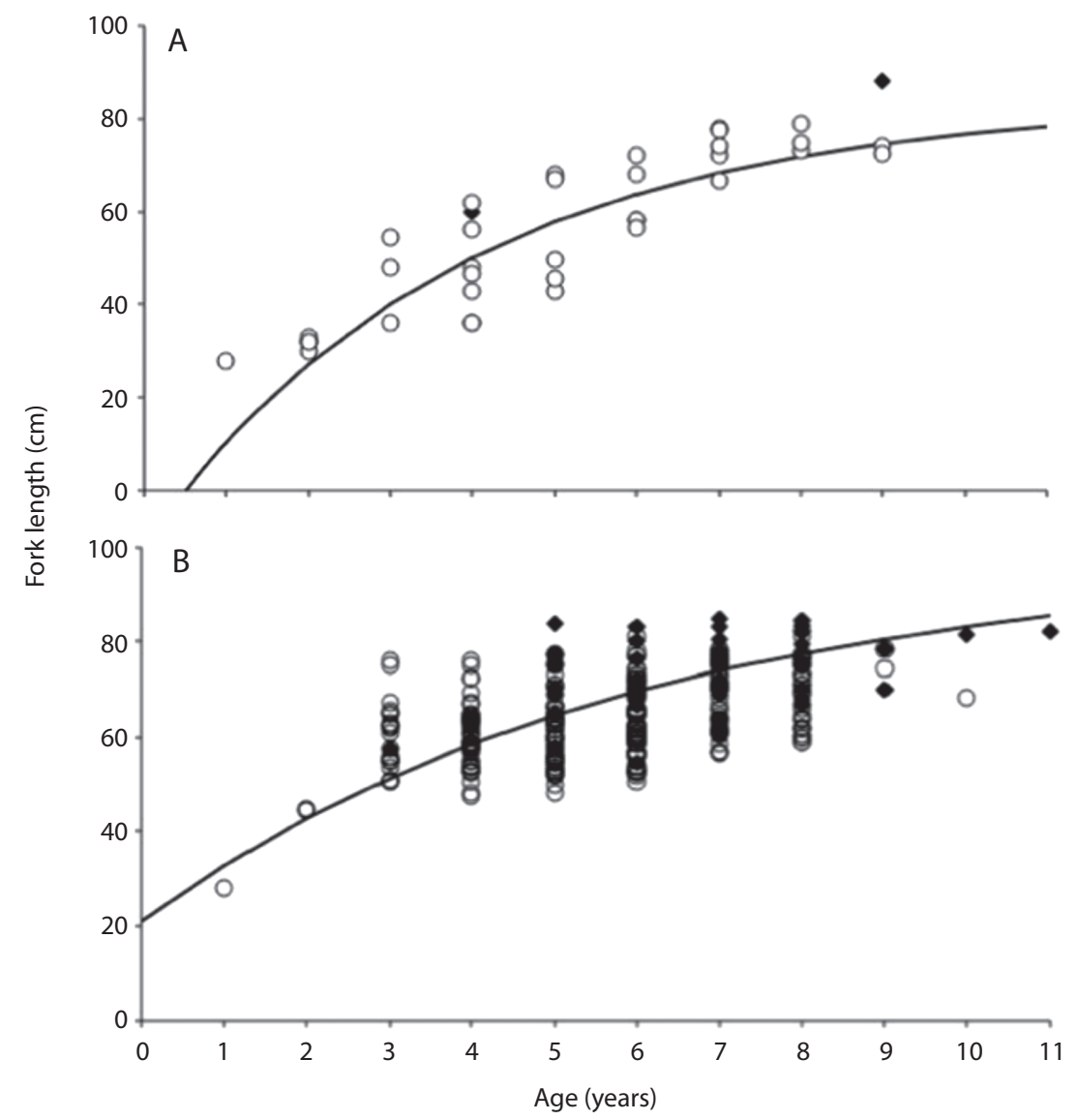

Fig. 7. The von Bertalanffy growth curves for males $(\mathrm{O})$ and females $(\boldsymbol{)})$ of $C$. undecimalis, riverine area, Tabasco, México.

age of the adult populations of the common snook are lower.

Because growth parameters of $C$. undecimalis that inhabit coastal and riverine areas of Tabasco, Mexico are significantly different, it is imperative that future research be conducted on migration and detailed population genetics in order to delineate the stock structure of this population. A permanent monitoring program of landing data and angler effort is necessary to support management programs. More important, future research focusing on harvest levels and mortality parameters should be conducted over a much larger area of Mexican coastal areas with the aim to conduct a multistate stock assessment, in order to determine stock condition.

\section{ACKNOWLEDGMENTS}

The authors are grateful to the fishermen and fishing cooperatives for sharing their data. Also, we are thankful to Ron Taylor (Fish and Wildlife Research Institute, FFWC) for his critical and useful comments on the manuscript. This study was funded by the Consejo Nacional de Ciencia y Tecnología (CONACyT) and El Colegio de la Frontera Sur (ECOSUR). 


\section{RESUMEN}

El robalo blanco Centropomus undecimalis representa un ingreso monetario significativo y un recurso alimentario para todas las comunidades rurales cercanas a su distribución. Se determinó la edad y crecimiento de esta especie. Los organismos se recolectaron mensualmente en los desembarcos de la pesca artesanal de las cooperativas de mayor contribución en la zona costera (Barra Bosque y San Pedro) y ribereña (San Pedro y Tres Brazos) entre julio 2006 y marzo 2008. La edad se determinó mediante otolitos seccionados. La edad estimada fue de 2 a 17 años. Mensualmente se estableció la formación anillos opacos y traslúcidos. Para ambas zonas de estudio agrupadas, se validó el retrocálculo por comparación de tres métodos (Fraser-Lee, Dahl-Lea y Whitney-Carlander), se encontraron diferencias significativas (ANCOVA, $\mathrm{p}<0.05$ ) entre el promedio de la longitud observada y la longitud retrocalculada. Las constantes de la ecuación de von Bertalanffy fueron calculadas para cada sexo y combinados, se empleó el método no lineal de Levenberg-Marquardt's. La edad estimada para el robalo blanco fue de 2 a 17 años. Se encontraron diferencias significativas en el crecimiento entre sexos ( $T^{2}$ Hotelling, $\left.\mathrm{p}<0.05\right)$. Los parámetros de crecimiento para ambos sexos fueron, zona costera: Barra Bosque $\mathrm{Lf}_{\mathrm{t}}=109.21\left(1-\mathrm{e}^{-0.21(\mathrm{t}+0.57)}\right)$, Barra San Pedro $\mathrm{Lf}_{\mathrm{t}}=94.56\left(1-\mathrm{e}^{0.27(\mathrm{t}+0.48)}\right)$, y para la zona ribereña: San Pedro $\mathrm{Lf}_{\mathrm{t}}=97.15\left(1-\mathrm{e}^{-0.17(\mathrm{t}+1.32)}\right)$ y Tres Brazos $\mathrm{Lf}_{\mathrm{t}}=83.77(1-$ $\left.\mathrm{e}^{-0.26(\mathrm{t}+0.49)}\right)$. Se encontraron diferencias significativas en las curvas de crecimiento de von Bertalanffy entre las poblaciones comparadas (RSS, $\mathrm{p}<0.05$ ).

Palabras clave: Centropomus undecimalis, edad, crecimiento, retrocálculo, pesca artesanal.

\section{REFERENCES}

Aliaume, C., A. Zerbi, J. Joyeux \& J.M. Miller. 2000. Growth of juvenile Centropomus undecimalis in a tropical island. Environ. Biol. Fish. 59: 299-308.

Aliaume, C., A. Zerbi \& J.M. Miller. 2005. Juvenile snook species in Puerto Rico estuaries: distribution, abundance and habitat description. Proc. Gulf Carib. Fish. Inst. 47: 499-519.

Beamish, R.J. \& G.A. McFarlane. 1983. The forgotten requirement for age validation in fisheries biology. Trans. Am. Fish. Soc. 112: 735-743.

Bernard, D.R. 1981. Multivariate analysis as a means of comparing growth in fish. Can. J. Fish. Aquat. Sci. 38:233-236.

Brennan, N.P., C.D. Meaghan \& M.L. Kenneth. 2006. Predator-free enclosures improve post-release survival of stocked common snook. J. Exp. Mar. Biol. Ecol. 335: 302-311.
Caballero, C.V. 2003. Estudio biológico pesquero del robalo Centropomus undecimalis en el suroeste de Campeche. Tesis de Maestría, Universidad Nacional Autónoma de México, México, D.F., México.

Cabrera, N.E. 2002. Edad y crecimiento del robalo Centropomus nigrescens Günter 1864 en el sistema lagunar Chacahua-Pastoría. Tesis de grado, Universidad del Mar, Campus Puerto Ángel, Oaxaca, México.

Cadima, E.L. 2003. Fish stock assessment manual. FAO, Roma, Italia.

Campana, S.E. 2001. Accuracy, precision and quality control in age determination, including a review of the use and abuse of age validation methods. J. Fish. Biol. 59: 197-242.

Campana, S.E. 2005. Otolith science entering the $21^{\text {st }}$ century. Mar. Freshwater Res. 56: 485-495.

Cappo, M., P. Eden, S.J. Newman \& S. Robertson. 2000. A new approach to validation of periodicity and timing of opaque zone formation in the otoliths of eleven species of Lutjanus from the central Great Barrier. Fish. Bull. 98: 474-488.

Chacón, D. 1993. Aspectos biométricos de una población de sábalo, Megalops atlanticus (Pisces: Megalopidae). Rev. Biol. Trop. 41: 13-18.

Chen Y., D.A. Jackson \& H.H. Harvey. 1992. A comparison of von Bertalanffy and polynominal functions in modeling fish growth data. Can. J. Fish. Aquat. Sci. 49: 1228-1235.

Chen F., Y. Chen \& D. He. 2008. Age and growth of Schizopygopsis younghusbandi younghusbandi in the Yarlung Zangbo River in Tibet, China. Environ. Biol. Fish. 82: 1-8

Ocean Warch North Pacific Demonstration Project. 2012. Coastwatch and SWFSC, Environmental Research Division, NOAA, EUA. (Downloaded: May 2012, http://las.pfeg.noaa. gov/oceanWatch/oceanwatch. php).

Ehrhardt, N. 1992. Age and growth of swordfish, Xiphias gladius, in the Northwestern Atlantic. Bull. Mar. Sci. 50: 292-301.

Francis, R.I.C.C. 1990. Back-calculation of fish length: a critical review. J. Fish. Biol. 36: 883-902.

Ibañez, A.L., J.R. Britton \& I.G. Cowx. 2008. Relationship between scale growth checks, circuli formation rate and somatic growth in Rutilus rutilus (L.) a fish farmreared cyprinid. J. Fish. Biol. 72: 1023-1034.

Kallianiotis, A., M. Torre \& A. Argyry. 2005. Age, growth, mortality, reproduction, and feeding habits of the striped seabream, Lithognathus mormyrus (Pisces:Sparidae), in the coastal waters of the Thracian Sea, Greece. Sci. Mar. 69: 391-404.

Lin, Y. \& W. Tzeng. 2009. Validation of annulus in otolith and estimation of growth rate for Japanese eel 
Anguilla japonica in tropical southern Taiwan. Environ. Biol. Fish. 84: 79-87.

Lorenzo, J.M., J.G. Pajuelo, M. Méndez-Villamil, J. Coca \& A.G. Ramos. 2002. Age, growth, reproduction and mortality of the striped seabream, Lithognathus mormyrus (Pisces, Sparidae), off the Canary Islands (Central-east Atlantic). J. Appl. Ichthyol. 18: 204-209.

Marshall, A.R. 1958. A survey of the snook fishery of Florida, with studies of the biology of the principal species, Centropomus undecimalis (Bloch). FL. Board Conserv. Mar. Res. Lab. Tech. Ser. 22-37 p.

McDowall, R.M. 1999. Different kinds of diadromy: different kinds of conservation problems. J. Mar. Sci. 56: 410-413.

Mejia, M.N. \& M.D. Lara. 2007. Edad y crecimiento del robalo blanco (Centropomus undecimalis) (Bloch, 1792) en el Puerto Barra San Pedro, municipio de Centla, Tabasco. Tesis de grado, Universidad Juárez Autónoma de Tabasco, Tabasco, México.

Melo, B.F.N. \& U.R. Felix. 2004. Estructura de tallas y edad del marlin rayado Tetrapturus audaz (Pisces:Xiphidae) en Cabo San Lucas, Baja California Sur, México. Rev. Biol. Trop. 52: 981-989.

Muller, R.G. \& R.G. Taylor. 2006. The 2006 stock assessment update of common snook, Centropomus undecimalis. Florida Marine Research Institute. St. Petersburg, Florida, USA.

Munday, P.L., L. Alyson, J. Hodges, J. Howard Choat \& N. Gust. 2004. Sex specific growth effects in protogynous hermaphrodites. Can. J. Fish. Aquat. Sci. 45: 1514-1524.

Patterson, H.M., R.G. Taylor \& R.S. McBride. 2005. Coastal origin of common snook, Centropomus undecimalis, in Florida Bay. Gulf Carib. Res. 17: 25-30.

Pauly, D., V. Christensen, S. Guenette, T.J. Pitcher \& D. Zeller. 2002. Towards sustainability in world fisheries. Nature 418: 689-695.

Perera-García, M.A., M. Mendoza-Carranza \& S. PáramoDelgadillo. 2008. Dinámica reproductiva y poblacional del robalo Centropomus undecimalis, en Barra San Pedro, Centla, México. Universidad y Ciencia 24: 49-59.

Perera-García, M.A., M. Mendoza-Carranza, W.M. Contreras-Sánchez, M. Huerta-Ortíz \& E. Pérez-Sánchez. 2011. Reproductive biology of common snook Centropomus undecimalis (Perciformes: Centropomidae) in two tropical habitats. Rev. Biol. Trop. 59: 669-681.

Peters, K.M., R.E. Matheson Jr. \& R.G. Taylor. 1998. Reproduction and early life history of common snook, Centropomus undecimalis (Bloch), in Florida. Bull. Mar. Sci. 62: 509-529.

Quiroga, B.C. \& C.F. Solís. 1999. Estado actual de la pesquería de robalo en México. Pesquerías Relevantes de México. XXX Aniversario del INP. SEMARNAP/ INP. (IV): 559-578.

Ricker, W.E. 1973. Linear regressions in Fisheries Research. J. Fish. Board Can. 30: 409-434.

Ricker, W.E. 1992. Back-calculation of fish lengths based on proportionality between scale and length increments. Can. J. Fish. Aquat. Sci. 49: 1018-1026.

Rico, V., J.M. Lorenzo \& J.A. González. 2001. Edad y crecimiento del besugo americano Beryx splendens Lowe, 1834 (Osteichthyes, Berycidae) en aguas de las islas Canarias. Bol. Inst. Esp. Oceanogr. 17: 121-128.

Rivas, L.R. 1986. Sistematic review of the perciform fishes of the genus Centropomus. Copeia 3: 579-611.

Saila, S.B., C.W. Recksiek \& M.H. Prager. 1988. Basic fishery science programs. A compendium of microcomputer programs and manual of operation. Dev. Aquacult. Fish. Sci. 18: 1-230.

Sokal, R.R. \& F.J. Rohlf. 1996. Biometry: The Principles and Practice of Statistics in Biological Research. Freeman, New York, USA.

Sparre, P. \& S.C. Venema. 1997. Introducción a la evaluación de recursos pesqueros tropicales, Parte 1 manual. FAO, Santiago de Chile, Chile.

Stevens, P.W., D.A. Blewett \& G.R. Poulakis. 2007. Variable habitat use by juvenile common snook, Centropomus undecimalis (PISCES: CENTROPOMIDAE): applying a life-history model in a southwest Florida estuary. B. Mar. Sci. 80: 93-108.

Tavares, L.E.R. \& J.L. Luque. 2003. Anew species of Acantholochus (Copepoda: Bomolochidae) parasitic on Centropomus undecimalis (Osteichthyes:Centropomidae) from the coastal zone of the State of Rio de Janeiro, Brazil. Mem. Inst. 98: 241-245.

Taylor, G.R., J.A. Wittington \& H.J. Grier. 2000. Age growth, maduration and protandric sex reversal in the common snook Centropomus undecimalis, from the east and west coasts of south Florida. Fish. Bull. 98: 612-624.

Tucker, J.W. \& S.W. Campbell. 1988. Spawning season for common snook along the east central Florida coast. Florida Scientist 51: 1-6.

Villamil, M.M., J.M. Lorenzo, J.G. Pajuelo, A. Ramos \& J. Coca. 2002. Aspects of the life history of the salema, Sarpa salpa (Pisces: Sparidae), off the Canarian 
Archipelago (central-east Atlantic). Environ. Biol. Fish. 63: 183-192.

Walford, L.A. 1946. A new graphic method of describing the growth of animals. Biol. Bull. 90: 141-147.

Walter, P.W.P. \& M.I. McCormick. 2004. Otolith-check formation and accelerated growth associated with sex change in an annual protogynous tropical fish. Mar. Ecol. Prog. Ser. 266: 201-212.

Wilson, J.A., L. Vigliola \& M.G. Meekan. 2009. The back-calculation of size and growth from otoliths: validation and comparison of models at an individual level. J. Exp. Mar. Biol. Ecol. 368: 9-21.

Zar, J.H. 1999. Biostatistical Analysis. Prentice-Hall, New Jersey, USA.

Zarza-Meza, A.E., J.B. Villalobos, C.P. Vásquez \& P.T. Álvarez. 2006. Cultivo experimental del robalo Centropomus undecimalis (Bloch, 1792) y chucumite Centropomus parallelus (Poey, 1860) (Perciformes: Centropomidae) en agua dulce en un estanque de concreto en Alvarado, Veracruz, México. Vet. Méx. 37: 327-333. 
